\title{
Representations of the Nature of Scientific Knowledge in Turkish
}

\section{Biology Textbooks}

\author{
Serhat Irez \\ Correspondence: Serhat Irez, Marmara University, Turkey \\ Received: March 31, 2016 Accepted: April 12, $2016 \quad$ Online Published: April 22, 2016 \\ doi:10.11114/jets.v4i7.1507 URL: http://dx.doi.org/10.11114/jets.v4i7.1507
}

\begin{abstract}
Considering the impact of textbooks on learning, this study set out to assess representations of the nature of scientific knowledge in Turkish $9^{\text {th }}$ grade biology textbooks. To this end, the ten most commonly used $9^{\text {th }}$ grade biology textbooks were analyzed. A qualitative research approach was utilized and the textbooks were analyzed using ethnographic content analysis. Results indicated that the majority of textbooks, despite recent science curriculum reforms in Turkey, failed to cover or present adequate information about the majority of the aspects of scientific knowledge considered in this study. The finding that the majority of textbooks reviewed in this study were misleading or had inadequate descriptions of science is worrying and has serious implications for promoting science literacy in Turkey. If the scientific literacy reform efforts of 2007 and 3013 are to be realized, these shortcomings must be addressed.
\end{abstract}

Keywords: nature of scientific knowledge, biology textbooks, scientific literacy

\section{Introduction}

Promoting scientific literacy has become one of the main aims of science education worldwide. Science educators generally agreed that in order to achieve scientific literacy, understanding the nature of scientific knowledge (NOSK) is also needed. Although there is no single "nature of scientific knowledge" that fully describes all scientific enterprise (McComas, 1998; Schwartz \& Lederman, 2002), science educators generally agree on the aspects of NOSK, of which a scientifically literate person should be informed (Driver, Leach, Millar, \& Scott, 1996; Lederman, 2007; Niaz, 2008; McComas \& Olson, 1998; Mesci \& Schwartz, 2016; Osborne, Collins, Ratcliffe, Millar, \& Duschl, 2003)

This agreement describes science as a special way of knowing. It is accepted that there are methods and standards in science, but they can vary from science to science and can, within science, been changed, and changed for the better (Chalmers, 1999). One of the central aspects of science is that all scientific knowledge, including 'facts', 'theories', and 'laws', is tentative. Reasons for this stem from several other aspects, such as (a) scientific knowledge has a basis in empirical evidence, (b) empirical evidence is collected and interpreted based on current scientific perspectives as well as personal subjectivity due to scientists' values, knowledge, and prior experiences, (c) scientific knowledge is the product of human imagination and creativity, and (d) the direction and products of scientific investigations are influenced by the society and culture in which the science is conducted (Schwartz \& Lederman, 2002, p. 207).

The scientific literacy movement has also found echoes in Turkey. The Turkish Ministry of Education has introduced many reforms in secondary science education in order to promote scientific literacy. This reform movement targeted both the structure and philosophy of secondary science education. The secondary biology curriculum, for example, has been revised twice, in 2007 and 2013. The new curriculum has presented a new vision for the aims, learning and teaching approaches, and methods of assessment for secondary biology teaching (Irez \& Han, 2011). More importantly, the new curriculum has put an emphasis on teaching and learning NOSK.

In this sense, 'Understanding Nature of Scientific Knowledge' has been described as an important learning area in the Secondary Biology Curriculum and teachers are informed that biology teaching should provide opportunities to students to discuss empirical bases of scientific knowledge, the nature of evidence, the tentative nature of scientific knowledge and factors leading to scientific change, methods in science, subjectivity and objectivity in science, the role of scientific community and the relationship between science and society. The curriculum suggested both explicit and implicit strategies in teaching and learning about NOSK. Towards this end, NOSK is included in the 9th grade biology 
curriculum as a separate section. Also, the curriculum suggested the use of inquiry based strategies and the history of science throughout the other units in order to provide the continuity of student learning about NOSK.

However, simply developing a curriculum designed to improve the understandings of NOSK does not guarantee that these understandings will improve (Phillips \& Chiappetta, 2007). If the reform for scientific literacy made in 2007 and 2013 are to be realized, all components of school science should adopt similar approaches.

In this sense, textbooks emerge as an influential component amongst the elements of school science, as they greatly influence the content taught (Yager, 1996). There seems to be little question regarding the importance of textbooks in science teaching (Chiappetta, Sethna, \& Fillman, 1993). For as long as science has been a school subject, textbooks have been highly influential representations and interpretations of the curriculum to be taught (Niaz, 2013). In school science, the textbook is accepted as the ultimate source of knowledge, provides the majority of instructional support beyond the teacher, and in many cases actually becomes the curriculum (Stake \& Easley, 1978). Many science teachers, new teachers in particular, use the assigned textbook as their content outline and story line for their courses (Chiappetta, Sethna, \& Fillman, 1993). A research study by ChiangSoong and Yager (1993) revealed that more than eighty percent of science teachers use their textbooks more than $90 \%$ of the time. Reliance on textbooks is more apparent when teachers are teaching outside their own area of expertise (Stern \& Roseman, 2004). Considering that NOSK is relatively an unknown area for many teachers, especially for those in Turkey (Irez, 2006), they are expected to rely on what textbooks present in teaching these issues. Further, students expect the textbook to be used as the source of nearly all information and as the framework from which all science is to be experienced (ChiangSoong \& Yager, 1993).

Given this situation, it is critical that these materials should be both scientifically accurate and educationally balanced (Chiappetta et al., 1993, Niaz, 2013, 2014; Phillips \& Chiappetta, 2007; Vesterinen, Aksela \& Lavonen, 2013). Chiappetta, Sethna and Fillman (1993) argue that one of the most fundamental aspects regarding the content of a science textbook is the accuracy in its descriptions of NOSK. In order for these instructional resources to better support school science, it is critical that they present many facets of NOSK. Such integration of NOSK with science content enables students to gain a more accurate understanding of what science is and how it is conducted (Chiappetta \& Koballa, 2002; Duschl, 1990; Meichtry, 1992). Having well written, understandable science textbooks that convey an accurate and balanced view of NOSK is a key to helping teachers meet the challenges they have in providing their students with an accurate view of the scientific enterprise (Phillips \& Chiappetta, 2007).

Towards this end, the major research questions that guided this study is how NOSK is represented in Turkish biology textbooks and whether this representation is compatible with the contemporary understanding of NOSK.Further, this study also aims to assess how much space, in terms of percentage of the total narration included in each textbook is devoted to NOSK and analyze the differences from textbook to textbook in NOSK treatment. Such an analysis of the textbooks is likely to provide information concerning the match of current goals and directions for science education in Turkey set by the 2007 and 2013 secondary biology curriculum reforms. Further, the results of the study will potentially give insights regarding the teaching and learning of NOSK in the nation's schools as the textbooks accurately define what teachers teach and what students are expected to learn.

\section{Method}

\subsection{Textbooks under Investigation}

Traditionally, physics, chemistry and biology are taught as separate subjects throughout the secondary biology curriculum in Turkey. NOSK is discussed and explained explicitly as a separate topic in the 9th grade biology curriculum. The units included in 9th grade biology are Life Science Biology, World of Living Things and Contemporary Environmental Problems. NOSK is discussed in the unit called 'Life Science Biology'. The biology curriculum suggests thirty-three hours should be devoted to this unit. The first topic of the unit is 'Nature of Scientific Knowledge and Biology' and the curriculum devotes six hours to this topic. Therefore, this study focused on the 9th grade biology curriculum and 9th grade biology textbooks. Table 1 offers details of the textbooks analyzed in the study. A total of ten commonly used biology texts were selected.

Amongst the textbooks, those by MEB, Dikey Publishing, and ATA Publishing have been assigned by the Turkish Ministry of National Education as the primary textbooks in all secondary schools in different regions of Turkey. These textbooks are distributed to students free of charge, so millions of students (depending on the region of their schools) use one of these textbooks as the primary source of nearly all information about NOSK.

The remaining seven textbooks are published by independent publishers. The most important criterion for choosing textbooks to be included in this study was their availability. In this sense, these seven textbooks were chosen as they are available in bookstores nationwide and are considered as commonly used by teachers and students as a 
supplementary resource to the textbooks assigned by the government. The content of these textbooks is also framed on the national curriculum and they aim to support science learning. The latest editions of all textbooks were used for the analysis.

Table 1 . List of $9^{\text {th }}$ grade biology textbooks reviewed in the study

\begin{tabular}{llll}
\hline Author(s) & Date of Publication & Title & Publisher \\
\hline Commission & 2013 & Secondary Biology 9 & MEB \\
Z. Arslan \& E. Unver & 2014 & Secondary Biology 9 & Dikey Publishing \\
B. Demirdizen & 2015 & Secondary Biology 9 & ATA Publishing \\
H.B. Ozturk & 2013 & 9th Grade Biology & BRY Publishing \\
B. Karaagac \& B. Peri & 2014 & Biology 9 & Palme Publishing \\
No information on authors & 2014 & B9 & FEM \\
A. Cingiz, M. Kara \& V. Otlu & 2013 & 9th Grade Biology & Final Publishing \\
B. Bostanci \& M. Aydogan & 2014 & Biology 9th Grade & Eksen Publishing \\
T. Celik & 2013 & 9th Grade Biology & FDD Publishing \\
No information on authors & 2014 & Biology 9th Grade & Zambak \\
\hline
\end{tabular}

\subsection{Methodological and Analytical Framework}

The main aim of this research is to assess how NOSK is represented in $9^{\text {th }}$ grade biology textbooks. To this end, a qualitative approach was employed and Ethnographic Content Analysis (ECA) described by Aitheide (1996) was chosen as an appropriate methodological framework. ECA is a systematic and analytical, but not rigid, approach to content analysis. Predetermined categories and variables initially provide guidance, however others are allowed and expected to emerge during the analysis, including an orientation to constant discovery and constant comparison of relevant situations, settings, styles, images, meanings, and nuances (Aitheide, 1996; Cakir, 2011).

For each textbook, reviewing started with locating the chapter or section where NOSK was discussed. Analyses began with coding data in which sentences providing information about NOSK were coded. In coding, 11 predetermined themes (Irez, 2009) were used. They included descriptions of science, characteristics of scientists, scientific method, empirical NOSK, tentative NOSK, nature of scientific theories and laws, inference and theoretical entities in science, subjective and theory-laden NOSK, social and cultural embeddedness of science and, imagination and creativity in science. The themes were not independent of one another as they represent components of a conception of NOSK. Therefore, some of the statements were placed within more than one theme as they applied to all these themes. This theme generation process helped the researcher to check the consistency, or lack thereof, between the statements in the textbooks regarding any aspect of NOSK. All instances of NOSK in all ten textbooks were analyzed and coded in this manner.

\section{Results}

As explained earlier, NOSK is only covered and described explicitly in the first unit of $9^{\text {th }}$ grade biology. The first topic of the unit is 'Nature of Scientific Knowledge and Biology'. All textbooks provided information about various aspects of scientific enterprise in this section. The narrative in this section was usually accompanied with the pictures of scientists, natural settings, and living organisms. Some of the textbooks also presented stories from the history of science to support their discussions and some provided activities and experiments in order to support student learning about various aspects of NOSK. There were review questions at the end of the section in all textbooks. Pages devoted to NOSK in the textbooks varied. Table 2 presents information on the total pages of each textbook, pages devoted to the explicit discussion on NOSK and percentages of the pages devoted to the discussion on NOSK in the textbooks.

As seen in the table, the percentage of the number of pages devoted to the explicit discussion on NOSK in the textbooks varied between $0.78 \%$ and $4.62 \%$. The textbook by MEB devoted 13 pages (4.62\% of the total pages) to the discussion on NOSK. This discussion was supported by a number of stories from the history of science, such as the story of the discovery of the structure of DNA by Watson and Crick, and the story of the discovery of Helicobacter pylori and elucidation of its role in gastritis and peptic ulcer disease by Marshall and Warren. There were several activities designed to support student learning, such as "the staircase" activity (Chalmers, 1999), which aims to emphasize the difference between observation and inference. The textbook by BRY, on the other hand, devoted only 2 pages to the discussion on $\operatorname{NOSK}(0.78 \%$ of the total pages). Here, the textbook preferred to present short explanations about various aspects of NOSK without seeking any support from the history of science or classroom activities. 
Table 2. Inclusion of NOSK in 9th grade biology textbooks

\begin{tabular}{lccc}
\hline Textbooks (by publisher) & Total Pages & Pages devoted to NOSK & \% \\
\hline MEB & 281 & 13 & 4.62 \\
Dikey & 222 & 7 & 3.15 \\
FEM & 326 & 10 & 3.06 \\
ATA & 208 & 5 & 2.40 \\
Final & 264 & 5 & 1.89 \\
Eksen & 224 & 4 & 1.78 \\
FDD & 208 & 3 & 1.44 \\
Zambak & 224 & 3 & 1.33 \\
Palme & 320 & 3 & 0.93 \\
BRY & 256 & 2 & 0.78 \\
\hline
\end{tabular}

\subsection{Descriptions of Science}

Typically, all textbooks started the section on NOSK with a description of science. Most of the textbooks (six of ten) described science as a 'body of knowledge'. What is also evident in these descriptions is an emphasis on the objectiveness of scientific knowledge.

Science is accumulated knowledge that has been gathered through observations and experiments (Dikey, p.21).

Science is a body of systematically collected knowledge... The aim of science is to help humankind by controlling and manipulating nature in accordance with our needs (Eksen p.10).

Science is accumulated knowledge that has been gathered through objective observations and experiments (Final p.15).

Science is a systematically collected knowledge through objective observations and experiments (BRY p.13).

Such descriptions of science are also important as they gave an impression to the reader that there is an existing truth or reality and science represents the way of reaching that reality or truth. This was given to the reader through the use of phrases like "collected knowledge". Having described science as a body of knowledge, the textbooks by ATA and Zambak, however, explicitly stated that scientific knowledge represents true knowledge:

Science is a body of knowledge which has been collected through observations and experiments, proven to be true and, arranged in a systematic way (ATA p.14).

Science consists of a range of activities to reach facts and arrange these in a systematic way. (Zambak p.8) The remaining four textbooks, on the other hand, presented more informed descriptions regarding the description of science. These textbooks described science as a way of knowing and emphasized that science is a human activity:

Science is an attempt to explain natural phenomena (MEB, p.6).

Science is a human activity to explain the workings of universe. (FEM, p.3)

Science is a way of learning and it helps us to understand natural world (Palme, p.9).

In these descriptions, science is portrayed as an activity to produce explanations, not a process of discovering (or collecting) what is out there. Having described science as an active, continuous and productive process, the textbook by FDD preferred to present a list about the characteristics of scientific enterprise:

Science is driven by curiosity

Science is a dynamic and continuous activity rather than being a static body of knowledge.

Tentativeness and uncertainty are characteristics of all sciences.

There are no certain truths in science

Science produces testable and falsifiable knowledge about nature, and this demarcates science from supernatural explanations. (FDD, 13)

\subsection{Characteristics of Scientists}

There is a worldwide belief amongst students that scientists should have certain characteristics compared to nonscientists (Ryan, 1987; Solomon, Duveen, \& Scott, 1994; Song \& Kim, 1999). DoganBora, Arslan and Cakiroglu (2006) for example, found that students involved in their study believed that scientists should have certain characteristics such as being objective, unbiased, intelligent and rational. Song and Kim (1999) reported that the source of this belief could be the media, journals and books, or experiences in school science. Irez (2009) pointed out that representations of scientists in textbooks could also be an influential factor in school science contributing to 
students' perceptions of the stereotypical images of scientists. He reported that all textbooks in his sample presented certain characteristics of scientists.

Similarly, four of the ten textbooks analyzed in this study presented characteristics that a scientist should have. The textbook by MEB, for example, presented characteristics such as being objective, determined, enthusiastic and patient. The other three textbooks, those by Eksen, FEM and, Zambak, provided a more comprehensive list of characteristics. For example, the characteristics noted in the textbook by Zambak were as follows:

Reaching scientific facts is a long and tiring activity. Scientists should be;

Objective,

Skeptical

Critical thinkers,

Curious and skilled observers,

Determined and patient,

Careful and conscientious

Able to choose the best method

Able to use the materials/equipment effectively. (p.13)

Without a doubt, most of these characteristics are valued by science and some of them have been cited by major international science standards documents (McComas \& Olson, 1998). However, Irez (2009) discussed that presenting these characteristics as "essentials" to be a scientist is misleading, inaccurate and potentially damaging for the image of science. He presents several reasons for this. First of all, he discusses some of these characteristics (such as being curious, being enthusiastic about your occupation) are valued by all institutions of society and are not unique to science. Second, characteristics such as being unbiased or relying on a "universal and stepwise" scientific method represent a distorted picture of science and scientific investigation. Third, it is impossible and inadequate to list all characteristics that are valued by science. Because, different scientific disciplines may require different qualities and such a list would never be complete. Furthermore, one may claim that there are some other important characteristics or abilities that should be in the list. Examples would be creativity, accurate record keeping and truthful reporting. Song and Kim (1999) also warn that describing a typical scientist within this framework has a potential of destroying students' interest in science instead of nursing it, and thus may alienate them from scientific careers if they do not believe that they have the prescribed characteristics.

The rest of the textbooks did not include any discussion about the characteristics required to be a scientist. They also did not explain that there are no essential characteristics required to be a scientist.

\subsection{The Empirical Nature of Scientific Knowledge}

A majority of the textbooks (seven of ten) emphasized the reliance of science on evidence. The textbooks by Dikey, BRY and, Palme did not include any discussion about the empirical base of scientific knowledge. In the other textbooks, typical discussions included descriptions of scientific knowledge as based on evidence, data, experimentation and observation about natural phenomena. The following exemplifies typical expressions that were given by these textbooks:

Scientific theories and laws necessarily require empirical evidence. (Eksen, p.13)

Science and scientific knowledge relies on evidence gathered through observations and experiments. Scientists, considering evidence obtained from observations and experiments and using their imagination and creativity, propose valid scientific claims. (Final p.16)

One of the most important aspects of science is that all scientific claims should be supported by evidence. (MEB, p.8)

Accumulated evidence can provide support, validation and substantiation for scientific claims, but will never prove those claims to be true (Lederman, Abd-El-Khalick, Bell, \& Schwartz, 2002). While the empirical base of scientific knowledge was commonly presented by the majority of the textbooks, none of the textbooks referred to the supportive role of evidence. The textbooks by FEM and Eksen, on the other hand, explicitly stated that evidence gathered through experiments and observations are used to prove scientific claims.

Experiments are processes to show a scientific fact, verify a law or prove a hypothesis. (FEM p.11) Scientific claims that are proven by observations conducted under the same conditions become facts. (Eksen, p.11). 


\subsection{Scientific Method}

The existence of recipe procedures that all scientists follow in scientific investigations is one of the most widely held misconceptions about science (Lederman et al., 2002; McComas, 1998). The analysis of the textbooks in this study revealed that this misconception is still being expressed in some of the textbooks. Indeed, the analysis revealed that six of the ten textbooks analyzed in this study presented the scientific method as a universal and stepwise procedure that all scientists follow. The textbook by Eksen, for example, emphasized that scientists should follow the phases of the scientific method:

All explanations and generalizations generated by science is a product of a special kind of procedure called the scientific method. The scientific method consists of a series basic of principles and phases that all scientists should follow. (Eksen, p.10)

This is a common expression that was presented in the other textbooks by FDD, BRY, Dikey, ATA and, Zambak. Further, all of these six textbooks presented the scientific method consisting of five to ten steps. For example, the textbook by Zambak presented the definition of the problem as the first step for any scientific investigation. This is followed by observation and data collection. The next step is the formulation of a hypothesis. According to the textbook, this is followed by making predictions and designing controlled experiments. If the results of the experiments verify the hypothesis, then the hypothesis becomes a theory and then a law, which is problematic itself. If the results of the experiments do not verify the hypothesis, a new hypothesis is formulated and the same procedure is repeated for the new hypothesis. The number and names of the steps of the scientific method varied in the other five textbooks. The textbooks by FDD and Eksen offered a similar scheme to the Zambak in describing the steps of the scientific method, whereas the remaining three textbooks described a five-step scheme, starting with defining the problem and ending with drawing conclusions.

Today many philosophers and historians of science point out that such descriptions of the stepwise and universal scientific method have little relation to the ways that science is actually practiced. From this perspective, the scientific method is not a single recipe: scientific investigation requires imagination and creativity. Reflecting a similar perspective, the textbooks by MEB, Palme, FEM and, Final did not describe scientific methodology as a set of standards and steps to be followed, but rather as an unstructured process involving careful planning, creativity, collaboration, competition, patience, and continuity. The textbook by MEB informed students that scientists use a variety of different methods and approaches when searching for answers to scientific problems. The approach or method to be used depends on the nature of the question, scientific discipline and the perspective of the scientist (MEB, p.8).

In a similar vein, the textbook by Palme explained that

There is not a formula for a successful scientific research. There is no single scientific method that scientists should strictly follow. There are many elements in scientific investigations such as careful planning, creativity, collaboration, competition, patience, continuity and, luck. Such variety in the elements of scientific inquiry makes science less structured than many people think. (Palme, p.9)

All of these textbooks mentioned general principles and/or processes of scientific inquiry, such as a description of the problem, literature review, data collection, data analysis, and reporting, but they did not present them as standards or steps of the scientific method.

\subsection{The Tentative Nature of Scientific Knowledge}

All scientific knowledge, including 'facts', 'theories', and 'laws', is tentative. As Claxton (1991) somewhat radically points out:

'... At each stage in the development of scientific ideas, what is 'obvious' today was 'ridiculous' yesterday and will be 'false' tomorrow' (p.80).

In their narrative about the status of scientific knowledge, eight of the textbooks, except for those by Eksen and, Zambak, emphasized the tentative nature of scientific knowledge.

$\ldots$ it is considered that there are no certain truths in science, that is, scientific knowledge is tentative (FEM, p.4).

Although scientific knowledge is durable and reliable, it is not certain and always open to change (FDD, p.13).

No matter how scientific knowledge seemed as certain to us, nobody can claim that it is $100 \%$ true (Dikey, p.18).

Although a majority of the textbooks explicitly pointed out the tentative NOSK, many of them failed to present reasons for change. Only three textbooks, those by FDD, MEB, and Final discussed the reasons leading scientific change. FDD, for example, explained that scientific knowledge changes in light of new evidence or new perspectives. 
The textbooks by MEB and Final presented more comprehensive explanations about the reasons for scientific change.

Scientific claims change as new evidence emerged and as existing evidence is reinterpreted in the light of new theoretical advances or changes in the cultural and social spheres. For example, fungi were classified in the plant kingdom until 1960s. But today, due to the advances in the field and changes in our understanding, plants and fungi are classified in different kingdoms (MEB, p.15).

The textbooks by Eksen and Zambak, on the other hand, did not mentioned about the tentative nature of scientific knowledge. On the contrary, these two textbooks presented various expressions which could lead misconceptions about the status of scientific knowledge in students' minds.

Scientific knowledge that is tested and verified under the same conditions is called fact. Therefore, facts are basic knowledge that everybody accepts (Eksen, p.11).

If the results confirm the predictions, the hypothesis becomes a fact... As a result of Pasteur's experiments, the idea that "life does not emerge from nonliving matter" became a fact (Zambak, p.11).

\subsection{The Relationship between Theories and Laws}

For many years, researchers repeatedly reported a potentially harmful misunderstanding amongst students and teachers concerning the nature and relationship between scientific theories and laws (Lederman, 1998; Lederman et al., 2002; McComas, 1998). This misunderstanding involves a belief that there is a developmental sequence and hierarchical relationship through which scientific ideas pass on their way to final acceptance as mature laws (Lederman, 1998; McComas, 1998). Individuals holding such misconceptions do not only believe that theories become laws depending on the availability of supporting evidence, and have greater status (Lederman, 1998), but also often fail to appreciate that all scientific knowledge in science is tentative as they see scientific laws as 'proven' scientific knowledge (McComas, 1998).

Therefore, a description of such important products of science in textbooks in a clear and informed way is of paramount importance. All textbooks analyzed in this study, except for the textbook by Dikey, provided explanations about the nature of scientific theories and laws. The textbook by Dikey did not include any discussion regarding the nature of scientific theories and laws. The other textbooks started their discussions by providing a description of scientific theory. All these textbooks pointed out the well sustained nature of scientific theories and informed that, despite scientific theories are well sustained, they are open to change. Following are examples of typical descriptions expressed in these textbooks.

In scientific terms, a theory can be described as an explanation about nature which is supported by a lot of evidence (FEM, p.13).

If a number of observations and experiments support a hypothesis, then the hypothesis becomes a scientific theory (FDD, p.16).

Hypothesis becomes a theory if it is supported through observations and experiments. Although scientific theories are supported by observations and experiments, they can change (Final, p.17).

With regard to the nature of scientific laws, however, descriptions provided by the textbooks were quite diverse. Two of the textbooks, those by Dikey and FDD, did not present any clear explanation regarding the issue. There was an unclear expression in the textbook by FDD. However, it is difficult to speculate if the textbook referred to scientific laws with this explanation.

Developed theories help scientists to reach universal rules. In this way, new rules are produced which would be used to find answers to new problems (FDD, p.16).

Four of the textbooks in the sample of the study presented a common misconception and claimed that scientific theories become scientific laws if they are proven and accepted by the scientific community. In line with their description of scientific laws as proven theories, these four textbooks also presented scientific laws as true accounts and explanations of natural phenomena.

If theories become scientific facts accepted by everyone, then, they are called laws. For example, Mendelian laws (BRY, p.14).

Laws are scientific facts accepted by all scientists... An important principle about scientific laws is their fixity (FEM, p.13).

Theories turn into scientific laws in time... Laws are scientific facts that are accepted as truths by all sciences. For example, Mendelian Laws (Final p.17).

Law: Scientific facts that are accepted by all sciences. They are supported by more valid knowledge and data 
comparing to theories. Mendelian Laws can be given as an example (Zambak, p.9).

The remaining four textbooks, on the other hand, did not refer to a hierarchical relationship in describing the nature of scientific laws. One of these textbooks by ATA described scientific laws as different forms of scientific knowledge compared to scientific theories.

A hypothesis become a scientific law if all tests show that it is consistent with the reality and if it enables us to make valid predictions about natural phenomena. Laws are more precise claims comparing to theories (ATA, p.17).

The textbooks by Palme, MEB and Eksen presented an informed description about the relationship between scientific theories and laws. These textbooks emphasized that scientific theories and laws are different types of scientific knowledge and that there is no hierarchical relationship between the two.

The concepts of scientific theory and law have different meanings... Scientific laws answer questions regarding "how" things happen in nature; theories explain laws and seek answers to "why" questions... there is no hierarchical relationship between theories and laws (Palme s.11).

Similarly, the textbook by MEB clearly indicated that scientific theories and laws are different kind of scientific knowledge.

Scientific laws describe how natural phenomena occur under controlled conditions. Scientific theories on the other hand, are well supported explanations of natural phenomena (MEB, p.15).

\subsection{Inference and theoretical Entities}

One of the important aspects of NOSK is about inference and theoretical entities in science. Inferences are statements about unobserved phenomena or entities. Scientific theories often posit the existence of unobserved entities, and therefore, cannot be directly tested (Lederman et al., 2002). Only indirect evidence can be used to support theories and establish their validity. This is an important aspect of science and should be explained to students with great care. Failure in understanding the nature of evidence and the role of inference in science may direct students towards a belief that science relies on direct evidence and, therefore, they may become suspicions about the validity of some of the scientific disciplines or research areas where there is a shortage of direct evidence (Irez, 2009). The inspection of the biology textbooks revealed that none of the textbooks in the study discussed the value of inference and theoretical entities in science.

\subsection{The Subjective NOS}

The textbooks in the study differed in their approaches to subjectivity in science. Four of the textbooks, those by

Dikey, BRY, Palme, and FDD, did not include any discussion or explanation regarding the subjective NOSK. The textbooks by Zambak, Eksen and, ATA, on the other hand, included statements and explanations indicating science is (and should be) an objective enterprise.

The first thing a scientist should consider is how s/he can contribute the common good of humankind... That is, s/he should think about if the research s/he is about to conduct would yield beneficial results for the humankind and should not behave emotionally... Scientists should not be under the influence of the ideas and data presented by other experts ... should be totally objective while making observations (Zambak, p.8).

Scientific knowledge is accumulated through objective observation and experiments ... [Scientists] should avoid bias in scientific studies ... (Eksen, p.10) Scientists should be objective ... (ATA, p.18).

No doubt that science values objectivity. However, scientists are no different in their level of objectivity than are other professionals. Like other professionals, scientists' theoretical and disciplinary commitments, beliefs, prior knowledge, training, experiences, and expectations, as well as their nationality, sex, and gender influence their work (Chalmers, 1999; Kuhn, 1970; Lederman, 1998; McComas, 1998; Ryan \& Aikenhead, 1992). All these background factors form a mindset that affects the problems scientists investigate and how they conduct their investigations, what they observe (and do not observe), and how they make sense of, or interpret their observations (Lederman et al., 2002). Three of the textbooks in this study (MEB, FEM and, Final) informed students about the subjective NOSK. The textbook by MEB, for example, having emphasized that 'science is a subjective and humane process,' explained:

Various factors such as field of expertise, training, prior knowledge and experiences form a mindset that affects the problems scientists investigate and how they conduct their investigations, what they observe and how they make sense of, or interpret their observations (MEB, p.13).

Similar explanations were given by the textbooks by FEM and Final:

Factors like individual characteristics of scientists, their education, experiences and field of expertise can affect their cognitive structures and therefore may affect the way they approach scientific problems (FEM, p.4). 
... Therefore, even though science values objectivity, scientists' various aspects such as individual values, perspectives, beliefs and experiences affect their work (Final p.16).

\subsection{Social and Cultural Influences on Science}

Science is practiced in a culture and the individuals involved in scientific work are the products of that culture. As a social activity, science inevitably reflects social values and viewpoints (Lederman et al., 2002). Closely related to the discussion on the subjective NOSK, the relationship between science and society was also ignored by the majority of the textbooks in the study. Except for the three textbooks (those by MEB, ATA and Final), none of the textbooks presented any explanation regarding how science and society interact. The textbook by

Final explained that scientific studies are affected by society and culture.

Science is affected by the society and culture in which it is practiced. Cultural aspects and expectations of the society determines how science will progress... (Final p. 17).

Similar explanations were given in the textbooks by MEB and ATA. The textbook by MEB, for example, provided a much detailed account regarding how science affects and is affected by culture and society. First of all, science is an initiative that is affected by the society in which it is practiced. As scientists are members of the society, their identity, ideas and interests reflect the expectations and values of the society. This affects the research areas that scientists will choose. Further, scientific research today requires financial support. The majority of scientific research is financed by various institutions in society. Society's expectations and beliefs affect which research projects will be supported by these institutions. In turn, scientific knowledge closely affects societal life and understanding. Findings of scientific research such the structure of the atom or decoding the genetic material have changed the societal life as well as our understanding of nature (MEB, p.16).

Apart from these explanations regarding the relationship between science and society, the textbooks by MEB and ATA also pointed out that science is a product of all cultures.

... scientific knowledge is not a product of one civilization or nation, it is a common product and value of all humankind (ATA, p.18).

\subsection{Creativity and Imagination in Science}

It is commonly accepted that the use of logic and close examination of evidence are necessary, but not usually sufficient, for the advancement of science (Lederman et al., 2002). Therefore, scientific ideas inevitably require and involve imagination and creativity. Science educators agree that students should be provided with opportunities to explore and discuss the creative and imaginative NOSK. Despite its importance, half of the textbooks in this study did not present any discussion about the role of creativity and imagination in science. The remaining textbooks, however, discussed the issue in various ways. The textbook by Eksen, for example, suggested that creativity is essential at the beginning of scientific research.

Hypothesizing is fundamentally a cognitive activity, which requires creativity (Eksen, p.12).

As presented in the Scientific Method section, the textbook by Palme considered that creativity and imagination are essential, especially in designing and running scientific investigations.

There are many elements in scientific investigations such as careful planning, creativity, collaboration, competition, patience, continuity and, luck. Such variety in the elements of scientific inquiry makes science less structured than many people think (Palme, p.9).

The textbooks by Final and FEM, on the other hand, reported that creativity and imagination play important roles in the interpretation of the results of scientific investigations.

... It should be noted that scientists' creativity and imagination contributed to many scientific discoveries.

For example, imagination played an important role in the discovery of DNA model by Watson and Crick ... For this reason, scientists making the same observations or looking at the same findings can end up with different interpretations (FEM, p.4).

Many philosophers working in the field of philosophy of science consider scientific knowledge as a product of creativity and imagination (Final p.16).

Amongst all the textbooks, only the tome by MEB explained that creativity permeates scientific inquiry throughout. It is required in the development of the earliest conceptions of a research question, in designing and conducting research, and, in elucidating the results. 


\subsection{General Overview of the Representations of NOSK in the Textbooks}

The findings concerning the representations of NOSK in Turkish Grade 9 biology textbooks are summarized in Table 3. This table presents the textbooks' representations of different aspects of scientific knowledge in relation to each other. It allows comparisons across the textbooks regarding their representations of NOSK. In the left column of the table are aspects of NOSK and statements about these aspects that have been frequently cited by recent science education reform documents (e.g., American Association for the Advancement of Science [AAAS], 1993; Turkish Ministry of National Education [MNE], 2007, 2013) and researchers in various studies (e.g., Lederman et al., 2002; McComas \& Olson, 1998; Osborne et al., 2003). These aspects and statements are considered as adequate statements in reflecting and highlighting at least some aspects of science. The significance of these aspects and statements is that they, when considered together, cover much of what is central to the description of what NOSK is (Irez, 2009) and will help reveal a complete picture of the textbooks' approach to NOSK. The textbooks investigated in this study are placed at the top row. The symbols ' $\sqrt{ }$ ' and ' $\mathrm{X}$ ' in each textbook's cell corresponding to each statement indicates the textbooks' agreement or disagreement with the statement in consideration. 'NR' means there is no reference in the textbook regarding that statement. The last column on the right side gives the number and percentage of the textbooks presenting ideas with the statement. By looking at these percentages, one can identify the problematic areas within the group. The last row at the bottom of the table, on the other hand, reveals the total individual scores of the textbooks. The reader can see each textbook's rate and percentage of agreement with all the statements.

By looking at the total number and percentages in the right column of the table, the reader can see that many aspects of NOSK were either presented in an uninformed way or not presented at all. For example, all the textbooks in the sample either presented certain characteristics that scientists should have (4) or did not mention any essential requirements to become a scientist. Similarly, although the majority of the textbooks emphasized the empirical base for scientific knowledge (7), none of them mentioned the supportive role of evidence. Two textbooks claimed that evidence is used to 'prove' scientific claims.

As seen in the table, while the majority of the textbooks (6) clearly indicated that scientific knowledge is tentative, most of them failed to explain the reasons for scientific change. Only three textbooks clearly pointed out that new evidence may cause change in scientific knowledge. Similarly, only three textbooks pointed out new ways of looking at existing evidence as a potential reason for scientific change whereas only two explained that changes in social context may also contribute to scientific change. The majority of textbooks (7) failed to present that there is not a hierarchical relationship between scientific theories and laws. Eight textbooks failed to point out that scientific laws, like all other forms of knowledge in science, are tentative. None of the textbooks drew attention to the inferential nature of scientific theories. The majority of the textbooks (7) failed to give reference to subjective NOSK. Only three textbooks mentioned that observations are based on theories and affected by values and beliefs that may account for differences amongst scientists. In a similar vein, the majority of the textbooks failed to present adequate information regarding the interpretation of data. Only three textbooks presented science as a product of culture and only two mentioned societal influences on scientific research. Only one textbook mentioned about the role of scientific community in establishing the validity of scientific claims. 
Table 3. Overall analysis of the representations of NOSK in $9^{\text {th }}$ grade biology textbooks

\begin{tabular}{|c|c|c|c|c|c|c|c|c|c|c|c|}
\hline \multirow{2}{*}{ Aspect of NOSK } & \multicolumn{10}{|c|}{ Textbooks } & \multirow{2}{*}{ Total } \\
\hline & BRY & Dikey & Zambak & Eksen & ATA & Palme & FDD & FEM & Final & MEB & \\
\hline \multicolumn{12}{|l|}{ Description of science } \\
\hline $\begin{array}{l}\text { Science as a way of } \\
\text { knowing } \\
\text { Scientists }\end{array}$ & $\mathrm{X}$ & $\mathrm{X}$ & $X$ & $\mathrm{X}$ & $\mathrm{X}$ & $\sqrt{ }$ & $\sqrt{ }$ & $\sqrt{ }$ & $\mathrm{X}$ & $\sqrt{ }$ & $\begin{array}{l}4 / 10 \\
(40 \%)\end{array}$ \\
\hline No essential characteristics & NR & NR & $X$ & $\mathrm{X}$ & NR & NR & NR & $\mathrm{X}$ & NR & $X$ & $\begin{array}{l}\mathbf{0} / \mathbf{1 0} \\
(\mathbf{0 \%})\end{array}$ \\
\hline $\begin{array}{l}\text { The empirical NOSK } \\
\text { Importance of evidence }\end{array}$ & NR & NR & $\sqrt{ }$ & $\sqrt{ }$ & $\sqrt{ }$ & NR & $\sqrt{ }$ & $\sqrt{ }$ & $\sqrt{ }$ & $\sqrt{ }$ & $\begin{array}{l}7 / 10 \\
(70 \%)\end{array}$ \\
\hline $\begin{array}{l}\text { Supportive } \\
\text { evidence }\end{array}$ & NR & NR & NR & $\mathrm{X}$ & NR & NR & NR & $\mathrm{X}$ & NR & NR & $\begin{array}{l}\mathbf{0} / 10 \\
(0 \%)\end{array}$ \\
\hline $\begin{array}{l}\text { Scientific method } \\
\text { No single scientific method }\end{array}$ & $\mathrm{X}$ & $X$ & $X$ & $\mathrm{X}$ & $X$ & $\sqrt{ }$ & $\mathrm{X}$ & $\sqrt{ }$ & $\sqrt{ }$ & $\sqrt{ }$ & $\begin{array}{l}4 / 10 \\
(40 \%)\end{array}$ \\
\hline $\begin{array}{l}\text { Is not a step-wise } \\
\text { procedure }\end{array}$ & $\mathrm{X}$ & $\mathrm{X}$ & $\mathrm{X}$ & $\mathrm{X}$ & $\mathrm{X}$ & $\sqrt{ }$ & $\mathrm{X}$ & $\sqrt{ }$ & $\sqrt{ }$ & $\sqrt{ }$ & $\begin{array}{l}(40 \%) \\
4 / 10 \\
(40 \%)\end{array}$ \\
\hline \multicolumn{12}{|l|}{ The tentative NOSK } \\
\hline $\begin{array}{l}\text { All scientific knowledge is } \\
\text { tentative }\end{array}$ & NR & $\sqrt{ }$ & $\mathrm{X}$ & $\mathrm{X}$ & $\sqrt{ }$ & NR & $\sqrt{ }$ & $\sqrt{ }$ & $\sqrt{ }$ & $\sqrt{ }$ & $\begin{array}{l}6 / 10 \\
(60 \%)\end{array}$ \\
\hline Due to new evidence & NR & NR & NR & NR & NR & NR & $\sqrt{ }$ & NR & $\sqrt{ }$ & $\sqrt{ }$ & $\begin{array}{l}\mathbf{3} / \mathbf{1 0} \\
(\mathbf{3 0} \%)\end{array}$ \\
\hline $\begin{array}{l}\text { New ways of looking at } \\
\text { existing evidence }\end{array}$ & NR & NR & NR & NR & NR & NR & $\sqrt{ }$ & NR & $\sqrt{ }$ & $\sqrt{ }$ & $\begin{array}{l}3 / 10 \\
(30 \%)\end{array}$ \\
\hline $\begin{array}{l}\text { Due to changes in social } \\
\text { context }\end{array}$ & NR & NR & NR & NR & NR & NR & NR & NR & $\sqrt{ }$ & $\sqrt{ }$ & $\begin{array}{l}2 / 10 \\
(20 \%)\end{array}$ \\
\hline \multicolumn{12}{|l|}{$\begin{array}{l}\text { Scientific theories and } \\
\text { laws }\end{array}$} \\
\hline Theories are well sustained & $\sqrt{ }$ & NR & $\sqrt{ }$ & $\sqrt{ }$ & $\sqrt{ }$ & $\sqrt{ }$ & $\sqrt{ }$ & $\sqrt{ }$ & $\sqrt{ }$ & $\sqrt{ }$ & $\begin{array}{l}9 / 10 \\
(90 \%)\end{array}$ \\
\hline Theories may change & NR & NR & $\sqrt{ }$ & $\sqrt{ }$ & $\sqrt{ }$ & NR & $\sqrt{ }$ & $\sqrt{ }$ & $\sqrt{ }$ & $\sqrt{ }$ & $\begin{array}{l}7 / 10 \\
(70 \%)\end{array}$ \\
\hline $\begin{array}{ll}\text { No } & \text { hierarchical } \\
\text { relationship } & \end{array}$ & $\mathrm{X}$ & NR & $\mathrm{X}$ & $\sqrt{ }$ & NR & $\sqrt{ }$ & NR & $\mathrm{X}$ & $\mathrm{X}$ & $\sqrt{ }$ & $\begin{array}{l}\mathbf{3} / 10 \\
(30 \%)\end{array}$ \\
\hline Laws may change & $\mathrm{X}$ & NR & $X$ & NR & $\sqrt{ }$ & NR & NR & $\mathrm{X}$ & $\mathrm{X}$ & $\sqrt{ }$ & $\begin{array}{l}2 / 10 \\
(20 \%)\end{array}$ \\
\hline \multicolumn{12}{|l|}{$\begin{array}{l}\text { Inference and theoretical } \\
\text { entities }\end{array}$} \\
\hline $\begin{array}{l}\text { Inferential nature of some } \\
\text { theories }\end{array}$ & NR & NR & NR & NR & NR & NR & NR & NR & NR & NR & $\begin{array}{l}\mathbf{0} / \mathbf{1 0} \\
(0 \%)\end{array}$ \\
\hline \multicolumn{12}{|l|}{ The subjective NOSK } \\
\hline $\begin{array}{l}\text { Observations are } \\
\text { theory-laden }\end{array}$ & NR & NR & $\mathrm{X}$ & $\mathrm{X}$ & NR & NR & NR & $\sqrt{ }$ & $\sqrt{ }$ & $\sqrt{ }$ & $\begin{array}{l}3 / 10 \\
(30 \%)\end{array}$ \\
\hline $\begin{array}{l}\text { Are affected by values and } \\
\text { beliefs }\end{array}$ & NR & NR & $\mathrm{X}$ & $\mathrm{X}$ & $\mathrm{X}$ & NR & NR & $\sqrt{ }$ & $\sqrt{ }$ & $\sqrt{ }$ & $\begin{array}{l}\mathbf{3 / 1 0} \\
(\mathbf{3 0} \%)\end{array}$ \\
\hline $\begin{array}{l}\text { Differences in data } \\
\text { interpretation }\end{array}$ & NR & NR & $X$ & NR & NR & NR & NR & $\sqrt{ }$ & $\sqrt{ }$ & $\sqrt{ }$ & $\begin{array}{l}3 / 10 \\
(30 \%)\end{array}$ \\
\hline \multicolumn{12}{|l|}{$\begin{array}{l}\text { Social and cultural } \\
\text { influences in science }\end{array}$} \\
\hline $\begin{array}{l}\text { Science as a product of } \\
\text { culture }\end{array}$ & NR & NR & NR & NR & $\sqrt{ }$ & NR & NR & NR & $\sqrt{ }$ & $\sqrt{ }$ & $\begin{array}{l}3 / 10 \\
(30 \%)\end{array}$ \\
\hline Society influences science & NR & NR & NR & NR & NR & NR & NR & NR & $\sqrt{ }$ & $\sqrt{ }$ & $\begin{array}{l}2 / 10 \\
(20 \%)\end{array}$ \\
\hline $\begin{array}{l}\text { Science as a culture within } \\
\text { itself }\end{array}$ & NR & NR & NR & NR & NR & NR & NR & NR & NR & $\sqrt{ }$ & $\begin{array}{l}1 / 10 \\
(10 \%)\end{array}$ \\
\hline $\begin{array}{l}\text { Creativity and } \\
\text { imagination in science }\end{array}$ & & & & & & & & & & & \\
\hline $\begin{array}{l}\text { Involves imagination and } \\
\text { creativity }\end{array}$ & NR & NR & NR & $\sqrt{ }$ & NR & $\sqrt{ }$ & NR & $\sqrt{ }$ & $\sqrt{ }$ & $\sqrt{ }$ & $\begin{array}{l}\mathbf{5} / 10 \\
(\mathbf{5 0 \%})\end{array}$ \\
\hline Total & $\begin{array}{l}1 / 22 \\
(5 \%)\end{array}$ & $\begin{array}{l}1 / 22 \\
(5 \%)\end{array}$ & $\begin{array}{l}3 / 22 \\
(14 \%)\end{array}$ & $\begin{array}{l}5 / 22 \\
(23 \%)\end{array}$ & $\begin{array}{l}6 / 22 \\
(27 \%)\end{array}$ & $\begin{array}{l}6 / 22 \\
(27 \%)\end{array}$ & $\begin{array}{l}7 / 22 \\
(32 \%)\end{array}$ & $\begin{array}{l}11 / 22 \\
(50 \%)\end{array}$ & $\begin{array}{l}15 / 22 \\
(68 \%)\end{array}$ & $\begin{array}{l}19 / 22 \\
(86 \%)\end{array}$ & $\begin{array}{l}74 / 220 \\
(34 \%)\end{array}$ \\
\hline
\end{tabular}

On the other hand, the reader can see each textbook's total score by looking at the bottom of the table. As seen in the table, the textbooks' individual performances ranged from $5 \%$ to $86 \%$. From this perspective, the reader can see that 8 out of 10 textbooks' individual performances were less than or equal to 50\%. Only two textbooks, those by Final and MEB, had scores above 50\%, the textbook by MEB achieving $86 \%$. The textbooks by BRY and Dikey were the least successful textbooks in presenting adequate information regarding NOSK. Both were rated at $5 \%$ by presenting only one idea consistent with the statements listed in the table. This performance may be expected from the textbook by BRY, as the textbook devoted two pages to the discussions on NOSK in total of 256 pages ( $0.78 \%$ of all pages). The textbook by Dikey, however, devoted seven pages for NOSK (3.15\% of all pages). Despite this coverage, the textbook 
failed to present any information on 18 of the 22 statements in the table. A general inspection of the pages where NOSK is discussed in the textbook revealed that, the authors of the textbook preferred to present an overview of the chronological history of biology without integrating any discussion about NOSK. The textbook by MEB emerged as the most successful as it covered the majority of the aspects of NOSK and presented informed views about these aspects. The mean score for all textbooks was $34 \%$, which means that they failed to cover or present adequate information about the majority of the aspects of NOSK considered in this study.

\section{Discussion}

As explained earlier, promoting student learning about NOSK as a fundamental dimension of scientific literacy has been emphasized in many international curriculum documents in the last 30 years. With the recognition of the importance of developing adequate understandings about NOSK in achieving scientific literacy, science educators focused their attention on assessing students' and teachers' understanding and developing effective teaching approaches and curricular materials for teaching and learning NOSK. Such movement found echoes in Turkey as well. Consequently, science education curriculum reform attempts in the last ten years underlined the importance of developing student understanding of NOSK. Considering the important role of textbooks in teaching and learning, textbooks are expected to present comprehensive and adequate explanations regarding NOSK.

The results of the study showed that two biology textbooks in the sample provided adequate descriptions of NOSK. The most successful textbook, the textbook by MEB, is one of the three that have been assigned by the Turkish Ministry of National Education as the primary textbook. However, the performances of the other two textbooks, those by Dikey and ATA, with regard to covering necessary aspects of NOSK and presenting them in an adequate manner, were quite poor with scores of $5 \%$ and $27 \%$ respectively. As explained, these textbooks are distributed to students free of charge, so millions of students (depending on the region of their schools) use one of these textbooks as the primary source of nearly all information about NOSK. This means that the vast majority of students would not get clear and adequate information about NOSK through these textbooks. Results indicate that the majority of the remaining seven textbooks would not help students in this manner.

A previous study by Irez (2009) assessed most frequently used five secondary school biology textbooks in Turkey to examine the nature and the quality of treatment given to NOSK. The investigation revealed a number of serious problems with the way NOSK is portrayed in textbooks. Science was generally portrayed as collection of facts, not as a dynamic process of generating and testing alternative explanations about nature. Irez concluded that the authors of the textbooks often appeared not to understand the processes well enough to explain them to students and presented various misleading and inadequate descriptions regarding scientific enterprise. Further, he found that some important aspects of science were neglected by textbooks.

In light of the findings of this study, it is difficult to conclude that important progress has been achieved in the way that NOSK is represented in biology textbooks. Findings of this research indicate that the majority of the biology textbooks failed to present adequate conceptions about many aspects of NOSK, or they did not present them at all. The discussions that the majority of the textbooks provided about the essential characteristics of scientists, scientific method, tentative NOSK, the relationship between scientific theories and laws, the role of inference in science, subjectivity in science and the relationship between science and society were often inadequate or non-existent.

The finding that the majority of textbooks reviewed in this study were found to be poor, misleading or inadequate descriptions of science is worrying and has serious implications for the promotion of science literacy in Turkey. It is clear that better textbooks that are scientifically accurate and educationally balanced are essential.

The question to be discussed is why the authors of these textbooks failed to present an adequate and informed image of science despite the role and importance of NOSK, which has been stressed in recent science education curriculum reforms in Turkey. Irez (2009) considers that the reason is multifaceted. He wrote that the majority of textbook authors in Turkey are themselves science teachers. It is well documented that Turkish science teacher education programs do not give precedence to the teaching of history and philosophy of science (Irez, Cakir, \& Dogan, 2008). Given this fact, Irez (2009) argues it is not surprising that the authors, as products of such an education, pictured uninformed views about NOSK in their textbooks. Further, Irez continues, the teachers using these curriculum materials are not knowledgeable enough about NOSK, they accept the authority of textbooks. As a result, the information given about NOSK faces no objection by science teachers and a valuable feedback mechanism which is necessary to correct scientifically inaccurate information presented in textbooks fails.

These discussions point out that curriculum change itself does not guarantee change in educational practices (Irez \& Cakir, 2010; Phillips \& Chiappetta, 2007). It is important to accept teacher education, curriculum and curriculum materials as a whole for quality in science education and undertake necessary critical and thoughtful steps accordingly (Irez, 2009). This involves restructuring science teacher education programs in a way to promote scientifically literate 
teachers and reconsidering the curriculum in a way that allows and promotes learning of science in a meaningful and acceptable way (Irez \& Cakir, 2006; Yager, Dogan, Hacieminoglu, \& Yager, 2012). Further, assessment in science education in both school and national levels should aim to assess learning of processes as well as products of science (Cakir, 2008). Only with this holistic approach can better science textbooks that actually support learning of worthwhile ideas help teachers build their own content and pedagogical knowledge.

\section{Acknowledgements}

This study was supported by the Scientific Research Projects Coordination Office of Marmara University, Istanbul/Turkey. Contract Grant Number: EGTD1103160126.

\section{References}

Aitheide, D. L. (1996). Qualitative media analysis. Thousand Oaks, CA: Sage.

American Association for the Advancement of Science (AAAS). (1993). Benchmarks for scientific literacy. New York: Oxford University Press.

Cakir, M. (2008). Constructivist approaches to learning in science and their implications for science pedagogy: a literature review. International Journal of Environmental \& Science Education, 4(3), 193-206

Cakir, M. (2011). Epistemological Dialogue of Validity: Building Validity in Educational and Social Research. Education, 4(132), 664-675

Chalmers, A. F. (1999). What is this thing called science? (3rd ed.). Buckingham: Open University Press.

Chiang-Soong, B., \& Yager, R. E. (1993). The inclusion of STS material in the most frequently used secondary science textbooks in the US. Journal of Research in Science Teaching, 30(4), 339-349. http://dx.doi.org/10.1002/tea.3660300403

Chiappetta, E. L., \& Koballa, T. R. (2002). Science education in the middle and secondary schools (5th edn.) Upper Saddle River. NJ: Merrill Prentice Hall.

Chiappetta, E. L., Sethna, G. H., \& Fillman, D. A. (1993). Do middle school life science textbooks provide a balance of scientific literacy themes? Journal of Research in Science Teaching, 30(7), 787-797. http://dx.doi.org/10.1002/tea.3660300714

Claxton, G. (1991). Educating the Inquiring Mind: The Challenge for School Science. London: Harvester Wheat sheaf.

Dogan-Bora, N., Arslan, O., \& Cakiroglu, J. (2006). Lise ogrencilerinin bilim ve bilim insani hakkindaki gorusleri. Hacettepe Universitesi Egitim Fakultesi Dergisi, 31, 32-44.

Driver, R., Leach, J., Millar, R., \& Scott, P. (1996). Young people's images of science. Buckingham: Open University Press.

Duschl, R. A. (1990). Restructuring science education: The importance of theories and their development. Teachers College Press.

Han, C. (2013). Ogretmenlerin islevsel paradigmalari ve egitim reformu. Trakya Universitesi Egitim Fakultesi Dergisi, 1(3), 59-79

Irez, S. (2006). Are we prepared?: An assessment of preservice science teacher educators' beliefs about nature of science. Science Education, 90(6), 1113-1143. http://dx.doi.org/10.1002/sce.20156

Irez, S. (2009). Nature of science as depicted in Turkish biology textbooks. Science Education, 93(3), 422-447. http://dx.doi.org/10.1002/sce.20305

Irez, S., \& Cakir, M. (2006). Critical Reflective Approach to Teach the Nature of Science: A Rationale and Review of Strategies. Journal of Turkish Science Education, 2(3), 19-35.

Irez, S., \& Cakir, M. (2010). Horizon of Science Education Reform in Turkey: Challenges Ahead. Ahi Evran Üniversitesi Kırşshir Eğitim Fakültesi Dergisi, 11(4), 79-96.

Irez, S., \& Han, C. (2011). Educational Reforms as Paradigm Shifts: Utilizing Kuhnian Lenses for a Better Understanding of the Meaning of, and Resistance to, Educational Change. International Journal of Environmental and Science Education, 6(3), 251-266.

Irez, S., Cakir, M. \& Dogan, O. (2008). Scientific literacy and the curriculum: the Turkish case. Conference of Asian Science Education. Kaohsiung, Taiwan.

Kuhn, T. (1970). The structure of scientific revolutions. Chicago: University of Chicago Press. 
Lederman, N. G. (1998). The state of science education: Subject matter without content. Electronic Journal of Science Education, 3(2), 1-12.

Lederman, N. G. (2007). Nature of science: Past, present, and future. In S. Abell \& N.G. Lederman (Eds), Handbook of research on science education, (pp: 831-879). New York: Routledge

Lederman, N. G., Abd-El-Khalick, F., Bell, R. L., \& Schwartz, R. S. (2002). Views of nature of science questionnaire: Toward valid and meaningful assessment of learners' conceptions of nature of science. Journal of research in science teaching, 39(6), 497-521. http://dx.doi.org/10.1002/tea.10034

McComas, W. F. (1998). The principal elements of the nature of science: Dispelling the myths. In W. F. McComas (Ed.), The nature of science in science education: Rationales and strategies (pp. 53-70). Dordrecht: Kluwer Academic Publishers.

McComas, W. F., \& Olson, J. K. (1998). The nature of science in international science education standards documents. In W. F. McComas (Ed.), The nature of science in science education: Rationales and strategies (pp. 41-52). Dordrecht: Kluwer Academic Publishers.

Meichtry, Y. J. (1992). Influencing student understanding of the nature of science: Data from a case of curriculum development. Journal of Research in Science Teaching, 29(4), 389-407. http://dx.doi.org/10.1002/tea.3660290407

Mesci, G., \& Schwartz, R. S. (2016). Changing Preservice Science Teachers' Views of Nature of Science: Why Some Conceptions May be More Easily Altered than Others. Research in Science Education, 1-23. http://dx.doi.org/10.1007/s11165-015-9503-9

Ministry of National Education (MNE). (2007). Ortaöğretim 9-12. Sinıflar Biyoloji Dersi Öğretim Programı. Ankara: MEB Basımevi.

Ministry of National Education (MNE). (2013). Ortaöğretim Biyoloji Dersi Öğretim Programı. Ankara: MEB Basımevi.

Niaz, M. (2008). What 'ideas-about-science' should be taught in school science? A chemistry teachers' perspective. Instructional Science, 36, 233-249. http://dx.doi.org/10.1007/s11251-007-9031-8

Niaz, M. (2013). Textbooks: Impact on Curriculum. Encyclopedia of Science Education, 1-4. Dordrecht: Springer. http://dx.doi.org/10.1007/978-94-007-6165-0_181-2

Niaz, M. (2014). Evaluation of Textbooks: Approaches and Consequences. Encyclopedia of Science Education, 1-4. Dordrecht: Springer

Osborne, J., Collins, S., Ratcliffe, M., Millar, R., \& Duschl, R. (2003). What 'Ideas-about-science' should be taught in school science? A Delphi study of the expert community. Journal of Research in Science Teaching, 40(7), 692-720. http://dx.doi.org/10.1002/tea.10105

Phillips, M. C., \& Chiappetta, E. L. (2007). Do middle school science textbooks present a balanced view of the nature of science. In annual meeting of National Association for Research in Science Teaching, New Orleans, LA.

Ryan, A. G. (1987). High school graduates' beliefs about science-technology- society IV: The characteristics of scientists. Science Education, 71(4), 489-510. http://dx.doi.org/10.1002/sce.3730710403

Ryan, A. G., \& Aikenhead, G. S. (1992). Students' preconceptions about the epistemology of science. Science Education, 76(6), 559-580. http://dx.doi.org/10.1002/sce.3730760602

Schwartz, R. S., \& Lederman, N. G. (2002). 'It's the Nature of Beast': The Influence of Knowledge and Intentions on Learning and Teaching Nature of Science. Journal of Research in Science Teaching, 39(3), 205-236. http://dx.doi.org/10.1002/tea.10021

Solomon, J., Duveen, J., \& Scott, L. (1994). Pupils' images of scientific epistemology. International Journal of Science Education, 16(3), 361-373. http://dx.doi.org/10.1080/0950069940160309

Song, J., \& Kim, K. S. (1999). How Korean students see scientists: The images of the scientist. International Journal of Science Education, 21(9), 957-977. http://dx.doi.org/10.1080/095006999290255

Stake, R. E., \& Easley, J. A. (1978). Case studies in science education. Urbana: University of Illinois Center for Instructional Research and Curriculum Evaluation.

Stern, L., \& Roseman, J. (2004). Can middle school science textbooks help students learn important ideas? Findings from Project 2061's curriculum evaluation study: Life science. Journal of Research in Science Teaching, 41(6), 538-568. http://dx.doi.org/10.1002/tea.20019

Vesterinen, V. M., Aksela, M., \& Lavonen, J. (2013). Quantitative analysis of representations of nature of science in 
Nordic upper secondary school textbooks using framework of analysis based on philosophy of chemistry. Science \& Education, 22(7), 1839-1855. http://dx.doi.org/10.1007/s11191-011-9400-1

Yager, R. E. (1996). Science/technology/society as a reform in science education. Albany, NY: State University Press.

Yager, S. O., Dogan, O. K., Hacieminoglu, E., \& Yager, R. E. (2012). The Role of Student and Teacher Creativity in Aiding Current Reform Efforts in Science and Technology Education. National Forum of Applied Educational Research Journal, 3(25), 1-24.

\section{$(\mathrm{Cc}) \mathrm{BY}$}

This work is licensed under a Creative Commons Attribution 3.0 License. 